\title{
STRATEGI PENGEMBANGAN PRODUK JAMBU KRISTAL DI ERA NEW NORMAL
}

\author{
Eko Setiawan*, Gangga Febrianto, Ramis Mashuri, Alfianta Dwi Harnadi, Maulidina \\ Ainur Rosida, Andita Niken Anggraini, Shinta Dwi Lestari, Hendra Hafidz Risalbi, Nur \\ Rezki Muhammad Sholeh, Hanifah Nur Yulinda Sari, Sevena Yasmin, Hisyam Nasher \\ Ibrahim, Firlana Asari Syaroni \\ Fakultas Agama Islam, Universitas Islam Malang \\ *Korespondensi email: ekosetiawan@unisma.ac.id
}

\begin{abstract}
ABSTRAK
Pandemi Covid-19 belum sepeuhnya berakhir. Oleh karena itu, masyarakat yang tergabung dalam UMKM Bumiaji Sejahtera harus bergotong-royong untuk bertahan tetap hidup selama masa pandemi akibat penurunan daya beli. Jambu kristal merupakan varietas baru jambu biji dimana memiliki daging buah yang tebal dan biji yang sedikit sehingga banyak digemari oleh masyarakat terbukti dengan permintaan yang bertambah setiap tahunnya. Besarnya permintaan produk olahan jambu kristal di Desa Bumiaji, tidak sebanding dengan variasi olahan produk yang ada. Maka inovasi produk perlu dilakukan untuk memenuhi permintaan dan pengembangan jambu kristal di Desa Bumiaji. Metode yang digunakan adalah metode studi kasus (case study) pada Usaha Mikro, Kecil, dan Menengah (UMKM) di Desa Bumiaji, yang berfokus kepada pengembangan produk buah jambu kristal. Hasil dari penelitian yakni berupa produk rempeyek daun jambu kristal untuk meningkatkan pemasaran. Kekurangan kreatifitas SDM yang ada, perlu dibarengi dengan adanya pelatihan inovasi produk yang intensif.
\end{abstract}

Kata Kunci: jambu kristal; inovasi; pengembangan.

\section{PENDAHULUAN}

Pandemi Covid-19 belum sepenuhnya berakhir. Risiko penyebaran dan penularan virus Corona masih menjadi ancaman (Tambunan, 2020). Sejak diberlakukannya PSBB (Pembatasan Sosial Berskala Besar), memang angka penularan Covid-19 menunjukkan penurunan (Mashabi, 2020). Beberapa daerah pun mulai berencana akan tidak lagi memberlakukan PSBB. Namun pada kenyataan pendemi virus Corona belum berakhir dan masih mengintai setiap waktu. Untuk itulah santer terdengar kita akan masuk pada kondisi new normal. "New normal' dalam kondisi pandemi masih berlangsung, berarti kita harus 'hidup berdampingan' dengan virus Corona sambil melakukan aktivitas sehari-hari dengan adaptasi yang baru. Yaitu dengan tetap memiliki kewaspadaan tinggi agar tidak tertular Covid-19. Salah satunya dengan mematuhi dan melakukan protokol kesehatan seperti yang dianjurkan oleh pemerintah (Bramasta, 2020).

Usaha Mikro Kecil dan Menengah (UMKM) merupakan kekuatan strategis dan penting dalam pembangunan ekonomi Indonesia. UMKM memiliki peran penting dalam penyediaan lapangan kerja, memberikan kontribusi signifikan terhadap pertumbuhan ekonomi dan memeratakan pendapatan (Rizal, Mustapita, \& Kartika Sari, 2020). Menurut Putra (2016) pada saat krisis jumlah Usaha Kecil Menengah dan Koperasi justru bertambah dari 99,8\% menjadi 99,9\% dari pelaku usaha di Indonesia. Sumbangan terhadap PDB juga 
naik dari 39,8\% menjadi 59,36\%. Menyadari betapa pentingnya peran UMKM, hampir semua pemerintah di negara sedang berkembang, termasuk Indonesia selalu berupaya menumbuhkangkan UMKM. Menurut Kotler \& Keller (2008) pengembangan produk adalah strategi untuk pertumbuhan perusahaan dengan menawarkan produk baru atau yang dimodifikasi ke segmen pasar yang sekarang. Mengembangkan konsep produk menjadi produk fisik untuk meyakinkan bahwa gagasan produk dapat diubah menjadi produk yang dapat diwujudkan.

Jambu kristal merupakan varietas baru jambu biji yang dikembangkan di Taiwan pada tahun 1991 kemudian dikembangkan di Indonesia pada tahun 2009 hingga saat ini (Herdiat, Dwiratna, \& Kendarto, 2018). Jambu kristal memiliki keunikan dalam hal tekstur dan bentuk pada umumnya. Keunggulan dari jambu biji kristal terletak pada ukuran, rasa, dan warnanya. Ukurannya tergolong sedang, dagingnya berwarna putih tebal dan bijinya sedikit, rasanya sangat manis dengan kandungan air sedikit sehingga teksturnya agak lembut apabila dikunyah seperti buah pir dan renyah (Pratidina, Syamsun, \& Wijaya, 2016). Produksi buahnya sangat banyak dalam satu musim, sangat cocok untuk dibudidayakan dan bernilai komersial. Sehingga banyak petani mulai menyadari akan peluang berbudiaya jambu kristal. Begitupula dengan petani di Desa Bumiaji yang tergabung dalam UMKM Bumiaji Sejahtera.

UMKM Bumiaji Sejahtera menjadi salah satu pembudidaya jambu kristal yang aktif di Desa Bumiaji. Berdasarkan analisis kelayakan usaha terhadap pembudidaya jambu kristal tersebut menunjukkan kondisi yang layak dan jumlah permintaan jambu kristal setiap tahunnya meningkat secara signifikan. Dengan meningkatnya budidaya jambu kristal yang bersumber dari empat lahan, maka juga dibarengi dengan banyaknya limbah daun jambu. Tantangan UMKM Bumiaji Sejahtera pada masa pandemi covid-19 memasuki new normal tidak dibarengi dengan sumber daya manusia yang mumpuni, sehingga produk olahan jambu yang ada tidak dimaksimalkan. Seperti limbah daun jambu, selain itu ada pula limbah kulit lemon. Sehingga perlu dilakukan proses inoovasi produk baru di UMKM Bumiaji Sejahtera untuk meningkatkan penjualan produk di era new normal pasca pandemi covid19. Hasil evaluasi peningkatan penjualan produk olahan jambu digambarkan dalam bentuk kuisioner sebagai dasar untuk perencanaan target penjualan produk yang maksimal, sehingga dapat meningkatkan pendapatan UMKM Bumiaji Sejahtera.

Mengingat masih berada dalam masa new normal, dan kondisi pandemi masih berlangsung, maka setiap UMKM diwajibkan mematuhi dan melakukan protokol kesehatan seperti yang dianjurkan oleh pemerintah. Sehingga UD. Buniaji Sejahtera mematuhi protokol dengan membuat tempat cuci tangan yang diperuntukan untuk para pengunjung yang datang ke UD. Bumiaji Sejahtera.

\section{METODE}

Adapun metode yang akan dilakukan dalam kegiatan pengabdian masyarakat ini adalah sebagai berikut:

1. Metode studi kasus (case study) pada Usaha Mikro, Kecil, dan Menengah (UMKM) di Desa Bumiaji.

2. Metode tanya jawab dan diskusi.

3. Metode Demonstrasi, meliputi pengenalan langkah-langkah pembuatan rempeyek daun jambu kristal.

4. Metode praktik, meliputi pembuatan dan pemasaran produk rempeyek daun jambu kristal.

5. Metode evaluasi, berupa umpan balik dari pihak UD. Bumiaji Sejahtera

Tahap pembuatan rempeyek terbagi dalam beberapa langkah, yaitu sebagai berikut: 
1. Tahap Persiapan

a. Mempersiapkan bahan dan alat untuk membuat rempeyek.

b. Mempersiapkan packaging, berupa desain, pencetakan kemasan

2. Tahap Pembuatan

a. Rebus daun jambu agar hilang aroma pahit dari daun.

b. Buat bumbu rempeyek, yang berupa bumbu halus dan tepung yang kemudian dicampurkan menjadi satu dengan rebusan daun jambu.

c. Kemudian goreng hingga matang dan tiriskan.

3. Tahap Finishing

Tahap akhir dari pengembangan inovasi produk ini adalah pengemasan produk, yang kemudian dipasarkan secara digital melalui market place.

\section{HASIL DAN PEMBAHASAN}

Program Pengabdian Masyarakat ini dibuat untuk memberikan pelatihan terhadap pengembangan produk di UD. Bumiaji Sejahtera yang terletak di Desa Bumiaji, Kota Batu sebagai upaya meningkatkan pendapatan UMKM, juga sebagai pengembangan daerah pariwisata. Kegiatan pelatihan pengembangan rempeyek ini diawali dengan pemberian tester resep rempeyek. Setelah itu, dilanjutkan dengan demonstrasi cara pembuatan secara langsung kepada UD. Bumiaji Sejahtera, Kota Batu.

\section{Tahap Persiapan}

Pada tahap persiapan ini tim pelaksana melakukan pemilihan bahan yang akan digunakan sebagai bahan dasar rempeyek, juga pemilihan kemasan yang akan digunakan seperti desain kemasan yang dibuat sendiri, pemilihan daun jambu yang dapat digunakan sebagai rempeyek agar tidak pahit saat dikonsumsi.

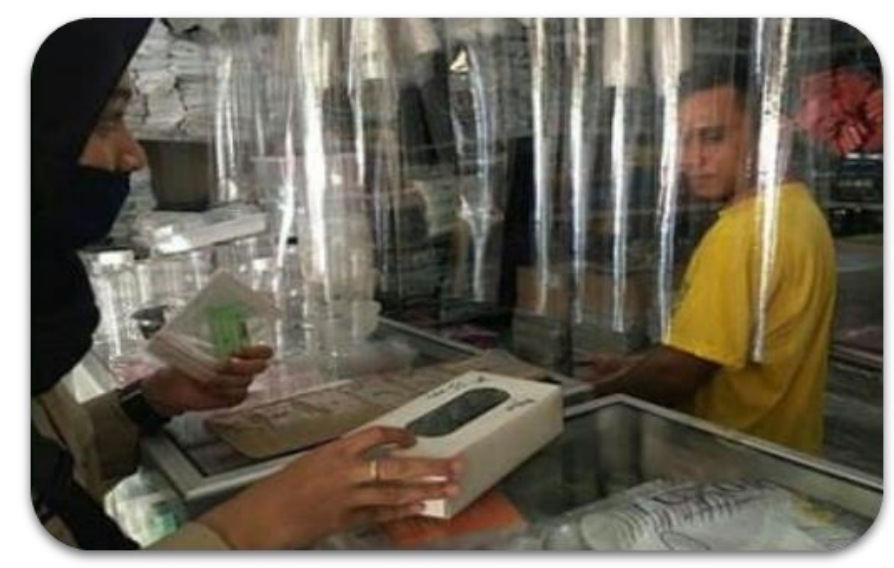

Gambar 1. Pembelian kemasan dan bahan

\section{Tahap Pembuatan}

Pada tahap pembuatan ini tim pelaksana melakukan praktik pembuatan tester resep, sekaligus kemasan produk secara mandiri terlebih dahulu, yang kemudian diberikan kepada pihak pemilik UD. Bumiaji Sejahtera sebagai usulan inovasi produk turunan dari buah jambu kristal dengan memanfaatkan daun-daun yang diolah kembali, setelah itu atas persetujuan dan ketertarikan pemilik. Kemudian dilakukan praktik pembuatan rempeyek daun jambu secara langsung pada ruang produksi UD. Bumiaji Sejahtera. 


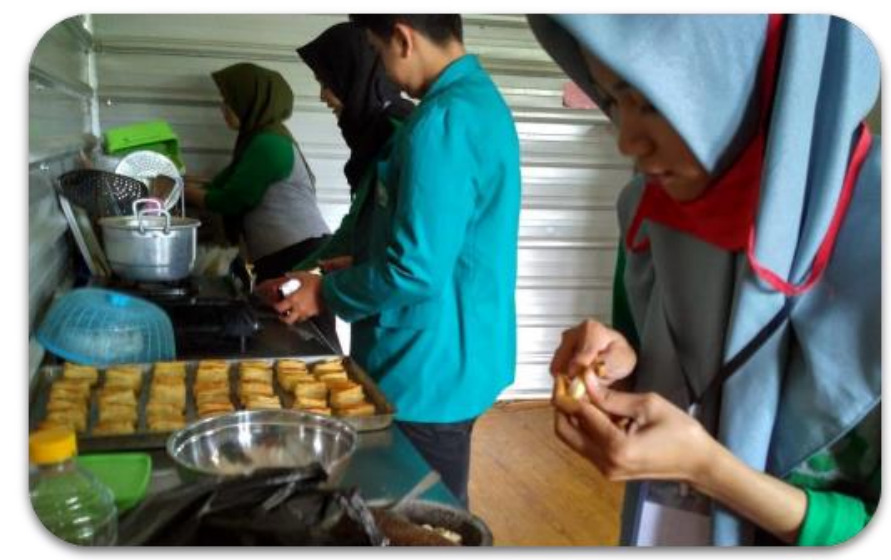

Gambar 2. Proses praktik secara langsung diruang produksi UD. Bumiaji Sejahtera

\section{Tahap Finishing}

Pada tahap finishing ini tim pelaksana melakukan pengemasan produk dan pemasaran secara digital melalui market place yang ada. Kemudian melakukan pendampingan terhadap SDM yang ada pada UD. Bumiaji Sejahtera untuk melek teknologi pemasaran melalui digital marketing.

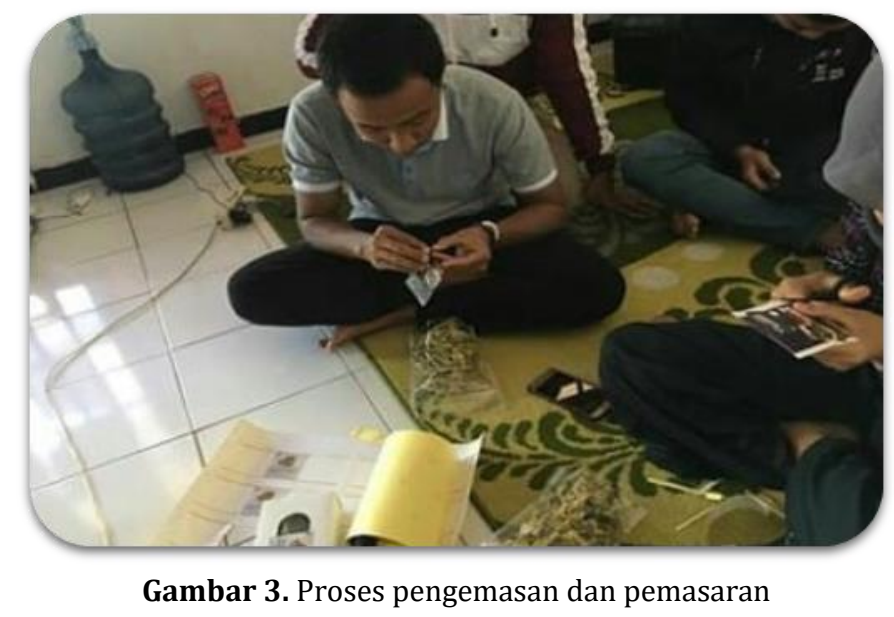

\section{KESIMPULAN}

Pengabdian Masyarakat berupa pembuatan rempeyek daun jambu kristal di Desa Bumiaji, Kota Batu ini berjalan dengan baik, sesuai dengan yang direncanakan. Dari hasil evaluasi berupa kuisioner yang diberikan kepada peserta memperoleh tanggapan positif dari masyarakat. Dengan adanya inovasi ini, dapat meningkatkan pendapatan juga pemanfaatan pohon jambu kristal sebagai produk turunan melalui olahan daun, sehingga memberi dampak positif pada aspek pengembangan produk dan desa wisata.

\section{DAFTAR RUJUKAN}

Bramasta, D. B. (2020). Mengenal Apa Itu New Normal di Tengah Pandemi Corona. Kompas.Com. Retrieved from https://www.kompas.com/tren/read/2020/05/20/063100865/mengenal-apa-itunew-normal-di-tengah-pandemi-corona-?page=all

Herdiat, I., Dwiratna, S., \& Kendarto, D. R. (2018). Evaluasi kesesuaian lahan tanaman jambu kristal sebagai upaya perluasan lahan di kabupaten sumedang menggunakan teknik analisis geospasial. In Seminar Nasional "Inovasi Pangan Lokal Untuk Mendukung 
Ketahanan Pangan" (pp. 80-86). Yogyakarta: Universitas Mercu Buana Yogyakarta. Retrieved from yogya.ac.id/index.php/Prosiding_IPPL/article/view/711 https://ejurnal.mercubuana-

Kotler, P., \& Keller, K. L. (2008). Manajemen Pemasaran (12th ed.). Jakarta: PT. Indeks, Jakarta.

Mashabi, S. (2020, September 3). 6 Bulan Pandemi Covid-19: Catatan tentang PSBB dan Penerapan Protokol Kesehatan. Kompas.Com. Retrieved from https://nasional.kompas.com/read/2020/09/03/09002161/6-bulan-pandemicovid-19-catatan-tentang-psbb-dan-penerapan-protokol?page=all

Pratidina, R., Syamsun, M., \& Wijaya, N. H. (2016). Analisis Pengendalian Mutu Jambu Kristal dengan Metode Six Sigma di ADC IPB-ICDF Taiwan Bogor. Jurnal Manajemen Dan Organisasi, 6(1), 1-18. https://doi.org/10.29244/jmo.v6i1.12180

Putra, A. H. (2016). Peran UMKM dalam Pembangunan dan Kesejahteraan Masyarakat Kabupaten Blora. Jurnal Analisa Sosiologi, 5(2), 40-52. https://doi.org/10.20961/jas.v5i2.18162

Rizal, M., Mustapita, A. F., \& Kartika Sari, A. F. (2020). Pelatihan Untuk Pengajuan Pembiayaan Mudharabah Perbankan Syariah Sebagai Peningkatan Kinerja UMKM. Jurnal Inovasi Hasil Pengabdian Masyarakat (JIPEMAS), 3(1), 15-22. https://doi.org/10.33474/jipemas.v3i1.2569

Tambunan, L. (2020). Virus corona di Indonesia: Kapan puncak pandemi akan terjadi setelah penerapan "new normal"? BBC News Indonesia. Retrieved from https://www.bbc.com/indonesia/indonesia-53380880 